\title{
Grape seed procyanidin B2 promotes the autophagy and apoptosis in colorectal cancer cells via regulating PI3K/Akt signaling pathway [Corrigendum]
}

Zhang R, Yu Q, Lu W, et al. Onco Targets Ther. 2019; 12:4109-4118.

On page 4109, the first sentence of Results in the Abstract section should read from "Results: The in vitro and in vivo data demonstrated that PB2 could promote the apoptosis of
CRC cells in a dose-dependent manner, which was significantly reversed by caspase 3 inhibitor." should read as "Results: The in vitro and in vivo data demonstrated that PB2 could promote the apoptosis of CRC cells in a dose-dependent manner, which was significantly reversed by PI3K inhibitor."

\section{Publish your work in this journal}

OncoTargets and Therapy is an international, peer-reviewed, open access journal focusing on the pathological basis of all cancers, potential targets for therapy and treatment protocols employed to improve the management of cancer patients. The journal also focuses on the impact of management programs and new therapeutic agents and protocols on patient perspectives such as quality of life, adherence and satisfaction. The manuscript management system is completely online and includes a very quick and fair peer-review system, which is all easy to use. Visit http://www.dovepress.com/ testimonials.php to read real quotes from published authors. 